\title{
Bajorų žemèvaldos slinktys XIX a. antrojoje pusėje: dvarų sekvestravimas ir konfiskavimas, rusų dvarininkų grupès susidarymas (Kauno ir Vilniaus gubernijos, 1863-1873 m.)
}

\author{
TAMARA BAIRAŠAUSKAITE் \\ Lietuvos istorijos institutas, Kražių g. 5, LT-01108 Vilnius \\ El. paštas: bairasauskaite@istorija.It
}

\begin{abstract}
Straipsnyje nagrinėjamas žemėvaldos veiksnio panaudojimas Rusijos imperijos politikoje vadinamajame Šiaurès vakarų krašte po $1863-1864 \mathrm{~m}$. sukilimo. Žemėvaldos apribojimas buvo taikytas kaip bausmẻ krašto bajorams už pasipriešinimą imperijai, taip pat kaip rusų nacionalizmo strategijos instrumentas. Pirmasis bajorųžemėvaldos apribojimo etapas, kuris buvo represinis, prievartinis, truko nuo 1863 iki 1873 metų. Straipsnyje siekiama aptarti pagrindinius apribojimo instrumentus - valdų sekvestravimą, konfiskavimą, draudimus, tarp kurių išsiskiria $1865 \mathrm{~m}$. gruodžio $10 \mathrm{~d}$. įstatymas, rusų dvarininkų įsitvirtinimo krašte pradžią; rekonstruoti žemèvaldos apribojimų taikymo eigą ir rezultatus Vilniaus ir Kauno gubernijose.
\end{abstract}

Raktažodžiai: 1863-1864 m. sukilimas, bajorų žemėvalda, sekvestravimas, konfiskavimas, „ne lenkų kilmès“ žemvaldžiai, rusų dvarininkai

\section{IVADAS}

Po 1863-1864 m. sukilimo imperinè politika Vakarų regione iš esmès pasikeitė: valdžia nutraukè dialogą su vietos elitu ir nusitaikè ị jo galios šaltini - privatinę nuosavybę, pirmiausia - i žemėvaldą. Nuosavybės nusavinimas buvo taikytas kaip bausmė už pasipriešinimą imperijai ir kaip rusų nacionalizmo strategija. Trys skirtingų tikslų siekiantys būdai - turto sekvestravimas ir konfiskacija, „lenkų kilmės“ bajorų elito stūmimas nuo žemès ir pastangos diegti rusų žemėvaldą - turèjo pakeisti krašto žemévaldos struktūrą, sumažinant joje bajorų žemvaldžių dalị, pakirsti bajorų elito materialinị galios pamatą, naikinti jo savarankiškumą ir griauti konsolidaciją, galiausiai pertvarkyti jo geografinę, socialinę ir kultūrinę erdvę.

Rusijos imperijos XIX a. antrosios pusès politikoje Vakarų regiono bajorų žemėvaldos apkarpymas laikytas itin svarbiu ši luomą „sutramdančiu“ įrankiu, nors jo panaudojimas prasilenkè su imperijos socialinès politikos principu remtis ị bajorų luomą ir užtikrinti jo teisę i privačią nuosavybę. XIX a. paskelbta specialių ịstatymų rinkinių, kuriuos buvo 
patogu naudoti praktikoje, taip pat darbų, nagrinejjančių rusų žemėvaldos raidą šiame regione $[49 ; 62 ; 68]$.

Bajorų dvarų konfiskavimas lenkų istoriografijoje laikytas didele tautos netektimi, todèl mejginta nustatyti jos mastą. Minètinas Lenkijos Karalystejje, Lietuvoje, Baltarusijoje ir Ukrainoje rusų valdžios XVIII a. pabaigoje - XIX a. pirmojoje pusejje konfiskuotų dvarų sąrašas, sudarytas Januszo Iwaszkiewicziaus. Jis nèra išsamus, todèl vertingas tik kaip bandymas ịvertinti bajorijos praradimus imperijos laikotarpiu [61, 43-46].

Rusų privačios žemévaldos susidarymą Vilniaus, Gardino ir Minsko gubernijose po 1863-1864 m. sukilimo nagrinèjo Wacławas Schmidtas [58], savo darbą rašęs tuoj po imperijos žlugimo, o medžiagą rinkęs Vilniaus archyvuose. Lietuvai ir Rusijai pasirašius 1920 m. liepos $21 \mathrm{~d}$. sutartị, buvo priverstas darbą nutraukti. Jis aptarè imperijos kolonijinę politiką ir jos pasekmes Šiaurès vakarų krašto visuomenei, pagrindinius 1864-1867 m. teisès aktus, padėjusius pamatus rusų žemėvaldai. Vèlesnị laikotarpị apžvelgė trumpai, nes nespèjo surinkti duomenų. Šiame darbe jis kèlè klausimą dèl tautybės sąvokos taikymo biurokratiniame diskurse, „ruso“ ir „lenko“ apibrèžimo teisès aktuose ir administracinejje praktikoje. Prieduose paskelbė Vilniaus, Gardino ir Minsko gubernijų dvarų, perejjusių rusų žemvaldžiams, sąrašus, tačiau jie nèra išsamūs.

Apie žemèvaldos veiksnio panaudojimą imperijos socialinèje politikoje rašè istorikai, nagrinejję bendrą imperijos politiką Šiaurès vakarų krašte XIX a. antrojoje pusėje. Ko gero, plačiausiai ją aptarè baltarusių istorikè Susana Sambuk [69]. Jos monografija, nors ir nelaisva nuo marksistinès paradigmos postulatų, vis dèlto sulaužè nuostatą ignoruoti bajorų klausimą istoriografijoje. Autorè aptarė praktiškai visas imperinės politikos gaires bajorijos atžvilgiu XIX a. antrojoje pusėje, paliesdama ir žemėvaldos apribojimo problemą. Ji diferencijavo imperijos politiką: didesnį spaudimą bajorai patyrẻ M. Muravjovo valdymo laikais, po 1866 m. ši politika švelnejjo, nes siekta užsitikrinti Vakarų krašto stambių žemvaldžių paramą. Rusų žemėvaldos diegimo politiką autorè vertino kaip socialinį, ekonominị ir politinị pasipriešinimą lenkams.

Rusų istorikè Ana Komzolova monografijoje, skirtoje M. Muravjovo ir jo ịpèdinių politikai Šiaurès vakarų krašte, aptarẻ bajorų teisių suvaržymą [66]. Šio tyrimo leitmotyvas - krašto administracijos formavimas, centro ir vietinès administracijos politikų kaita, nesutarimai dèl Šiaurès vakarų krašto integracijos strategijų ir metodų. Lenkų bajorų žemévaldos apribojimo ir rusų žemèvaldos sklaidos veiksnį imperijos politikoje istorikè vertina panašiai kaip S. Sambuk, pabrèždama, kad naujieji krašto administratoriai atsisake M. Muravjovo agrarinès politikos, linko daryti nuolaidų režimui lojaliems vietiniams žemvaldžiams ir nesureikšminti rusų dvarininkų ịsitvirtinimo krašte.

I žemèvaldos veiksnị imperijos politikoje Pietvakarių gubernijose atkreipè dèmesị D. Beauvois, tyręs žemès problemą dešiniakrantėje Ukrainoje 1863-1914 metais. Jo manymu, sistemingas bajorų žemėvaldos apkarpymas XIX a. antrojoje puseje buvo nuožmiausias lenkų civilizacijos naikinimo etapas. Ukraina, kuri mažiausiai prisidejjo prie sukilimo, tapo aršios lenkų ir rusų kovos dèl žemės arena. Lenkams žemè buvo sakralinė vertybė, paskutinis tėvynès gynimo bastionas, o rusams - veiksmingas ginklas priversti paklusti pakèlusius ginklą prieš imperijos valdžią. D. Beauvois išskiria du bajorų žemèvaldos apribojimo po sukilimo laikotarpius. Jo nuomone, 1863-1865 m. ženklino akla neapykanta ir nuožmūs veiksmai. Jis aptarè visą kompleksą valdžios priemonių, nutaikytų į žemvaldžius: nuo planų masiškai iškeldinti bajorus iki į iždą nusavintų valdų išpardavimo. Šis laikotarpis baigèsi $1865 \mathrm{~m}$. liepos 23 d. instrukcija, kurioje aptartos dvarų pardavimo rusams lengvatinėmis sąlygomis 
taisyklès. Antrasis laikotarpis - 1865-1875 m., kai prieš bajorų žemėvaldą nukreipta politika tapo nuoseklesnè ir labiau apgalvota. Vienas šios politikos akcentų - $1865 \mathrm{~m}$. gruodžio $10 \mathrm{~d}$. ịsakas, uždraudęs lenkų kilmès asmenims, pirmiausia bajorams, pirkti žemę devyniose Šiaurès vakarų ir Pietvakarių gubernijose. D. Beauvois šị ịsaką laiko stipriausiu rusifikacijos ginklu, nors teigia, kad šio įsako nesilaikymas sumažino galimus lenkų bajorų nuostolius. Finansinị smūgị turèjęs suduoti $10 \%$ kontribucijos mokestis, kuriam nustatyti $1866 \mathrm{~m}$. buvo issteigtos specialios komisijos, vertinusios dvarų pajamas [54, 21-27, 41]. Tačiau, D. Beauvois manymu, imperijos valdžiai nepavyko pakirsti lenkų bajorų žemėvaldos Ukrainoje: čia buvo konfiskuoti 144 dvarai iš 13601 regiono dvaro, o rusams atiteko 1736 dvarai [54, 34, 38-39]. Nevykusios žemėvaldos apribojimo akcijos priežasčių, jo manymu, būta ịvairių, tarp jų - pasikeitusi imperatoriaus nuostata po $1866 \mathrm{~m}$. balandžio $4 \mathrm{~d}$. pasikèsinimo ị jo gyvybę, kai jam prireikè aukščiausio visuomenės sluoksnio paramos, siekis išlaikyti Rusijos tarptautinị autoritetą, didejjantis bajorų žemvaldžių servilizmas. Valdžia keitė draudimų skalę ir ilgainiui atsisakè autoritarinių žemès nusavinimo metodų [54, 28-40].

Tą patị reiškinị - žemès nusavinimą po sukilimo - kiek kitaip vertina lenkų istorikas Romanas Jurkowskis [57, 25-62]. Monografijoje, kurios pagrindinis objektas - XIX a. antrosios pusès bajorų žemès ūkio draugijos šešiose Šiaurès vakarų krašto gubernijose (dab. Baltarusija ir Lietuva) ir jų veikla, jis aptaria privačios žemėvaldos padèti po sukilimo. Kaip ir D. Beauvois monografijoje, pagrindinis šio krašto žemės savininkas yra bajoras lenkas, 1863 m. Vilniaus, Kauno, Gardino ir Minsko gubernijose valdęs 93,2 \% dvarų ir 82,2 \% žemès, kuri po sukilimo buvo apkarpyta [57, 38]. Žemèvaldos kaita nebuvo pagrindinis tyrimo objektas. Autoriui labiau rūpejo sukurti bendrą žemėvaldos vaizdą, matyt, dèl to jis tik probėgšmais, remdamasis XIX a. statistika, ano meto ir šiuolaikine istoriografija, aptarè, jo manymu, svarbesnes jị dominančio laikotarpio problemas: trumpai paminėjo dvarų sekvestravimą ir konfiskaciją, aptarè, nors ir nenuosekliai, rusų žemévaldos plètros teisinị pamatą. Pabrèždamas oficialios statistikos nepatikimumą jis bandė operuoti nepalyginamais skaičiais, o tai leido pastebėti tik bendrą tendenciją: rusų žemėvalda krašte plito, tačiau jos dalis bendroje žemėvaldos struktūroje liko maža. Kadangi autorius daugiausia rèmèsi istoriografija, apsiribodamas duomenimis apie dabartinę Baltarusijos teritoriją, Vilniaus (rašo tik apie 4 „baltarusiškas“ apskritis), o ypač Kauno gubernijų bajorų žemėvaldos būklè po sukilimo šiame darbe pateikiama fragmentiškai. Be to, autorius naudojosi nepatikrintais duomenimis ir pakartojo ị istoriografiją ịsivèlusias klaidas [57, 25-52]. Apie $1865 \mathrm{~m}$. gruodžio 10 d. įsako pasekmes rašè Januszas Smykowskis [59]. Jo darbas yra paremtas skelbtais XIX a. šaltiniais ir XX a. pradžios veikalais, aptariančiais rusų žemèvaldos Šiaurès vakarų krašte klausimą, todèl autorius tik pakartojo pagrindinius lenkų istoriografijos teiginius apie nevykusią imperijos politiką ir lenkų žemvaldžių vyravimą regione.

Bajorų žemèvaldos kaitos teisinị aspektą po sukilimo nagrinėjo baltarusių istorikai. Viačeslavui Paniucičiui labiau rūpèjo žemèvaldos klausimo sprendimas atsižvelgiant ị tautinį veiksnị: lenkų žemėvaldos apribojimas, rusų ir baltarusių valstiečių žemèvaldos plètros tendencijos, žydų dalyvavimo žemės valdyme formos. Jis aptarè įstatymus, apribojusius lenkų teisę dalyvauti žemės apyvartoje, taip pat rusų žemévaldos plètros teisinị pamatą [67]. Baltarusijos gubernijų (Gardino, Minsko, Mogiliavo ir Vitebsko) bajorų žemévaldos raidą XIX a. antrojoje pusėje tyrè Anatolijus Žytko, aptaręs svarbesnius žemėvaldą reguliuojančius įstatymus ir konkrečius jų igyvendinimo rezultatus šiose gubernijose [64, 96-134].

Teisini žemévaldos apribojimo XIX a. antrojoje pusejje aspektą Lietuvos istoriografijoje nagrinèjo L. Bičkauskas-Gentvila. Viename straipsnyje aiškinamas „lenkų“ ir „rusų“ 
kilmès žemvaldžiu priešpriešos panaudojimas imperinèje politikoje, aptariami kai kurie svarbesni lenkų kilmès žemvaldžių teises ribojantys ịstatymai, tačiau pagrindinis jo straipsnių objektas yra valstiečiai, jų privačios nuosavybės teisių apribojimai, imperijos agrarinė politika. Autoriaus manymu, taip buvo siekiama išlaikyti stambią dvarininkų žemėvaldą Lietuvoje ir Baltarusijoje. Kitame straipsnyje nagrinejjami privačios žemèvaldos pokyčiai XIX a. antrojoje pusejje, aptariama agrarinè politika Šiaurès vakarų krašte, Vilniaus, Kauno ir Gardino gubernijų gyventojų žemėvaldos būklè, todẻl užsimenama apie bajorų dvarų sekvestravimą, konfiskaciją, kontribuciją ir rusų žemėvaldos formavimą [55; 56]. Autorius remiasi archyvų šaltiniais, tačiau jie naudojami selektyviai ir iliustratyviai: siekiama pagrịsti kapitalizmo plètros ir valstiečių ūkio kapitalizacijos apribojimo, stambių bajorų dvarų ir vokiečių žemèvaldos palaikymo koncepciją.

Draudimų žemėvaldos srityje ir kontribucijos mokesčio reikšmę imperijos tautinėje politikoje apžvelgè Darius Staliūnas. Jam rūpejjo išsiaiškinti, kaip rusų aukščiausioji valdžia ir vietos valdininkai, iggvendindami žemèvaldos ir privačios nuosavybės apribojimo įstatymus, kurdami rusų atkèlimo ị Šiaurès vakarų kraštą planus, skyrẻ bajorus pagal tautini požymí, kaip formavosi valdžios nuostatos dèl rusiško elemento ịkurdinimo. Kartu jis aptarè skirtingas valdžios atstovų pozicijas rengiant žemèvaldos apribojimo teisinę bazę [60, 120-149].

Paminèti darbai sukūrẻ gana išsamų vaizdą imperinès politikos, nutaikytos ị vietinius bajorus, kai socialinės ir tautinės politikos instrumentu tapo žemės perskirstymas. Žemèvaldos klausimas Vakarų regione neprarado reikšmès imperijos politikoje praktiškai iki Rusijos imperijos žlugimo ir liete visus socialinius sluoksnius. XIX a. antrojoje pusejje - XX a. pradžioje imperija ji sprendè vadovaudamasi pirmiausia ne ekonominiais, bet politiniais motyvais, taip deformuodama modernèjančios visuomenès socialinę ir ekonominę raidą.

Šių deformacijų pagrindinè priežastis ir objektas buvo XIX a. viduryje sukilusi „lenkų kilmès" bajorija, kurią imperija laikè savo priešu ir konkurentu kovoje už įtaką visuomenèje, todèl skirtingoms visuomenès grupėms taikyti apribojimai žemèvaldoje priklausè nuo „lenkų kilmès“ bajorams taikytų apribojimų. Straipsnio tikslas - pradèti skelbti rezultatus nuoseklių tyrimų, kodèl ir kaip kito bajorų žemėvalda XIX a. antrojoje pusejje - XX a. pradžioje. Šiame straipsnyje aptariamas pirmasis bajorų žemévaldos apribojimo etapas, kurio pradžia laikytini $1863 \mathrm{~m}$., kai prieš sukilèlius buvo taikomos ekonominès represijos, o sąlygine pabaiga - 1873 m., kai buvo paskelbta, kad nutraukiamas bajorų dvarų konfiskavimas.

Pirmajam bajorų žemėvaldos apribojimo etapui būdingas represinis, prievartinis pobūdis, todèl siekiama aptarti pagrindinius apribojimo instrumentus - valdų sekvestravimą, konfiskavimą, draudimus, tarp kurių išskirtinis yra $1865 \mathrm{~m}$. gruodžio 10 d. ịstatymas, ir rusų dvarininkų įsitvirtinimo krašte pradžią, rekonstruoti šių instrumentų taikymo eigą ir rezultatus Vilniaus ir Kauno gubernijose.

\section{DVARU SEKVESTRAVIMAS IR KONFISKAVIMAS}

Dvarų, žemės sklypų, namų, kilnojamosios nuosavybės sekvestravimą imperijos valdžia taikè sukilèliams kaip bausmę ir turtinę atsakomybę. Be to, jai tai buvo operatyvi priemonè pakirsti sukilimo materialinę bazę: dvarai aprūpino sukilèlius maistu, pašarais, ginklais ir drabužiais. Sukilimas Lietuvoje ir Baltarusijoje prasidèjo 1863 m. vasario mèn., o jau $1863 \mathrm{~m}$. kovo $15 \mathrm{~d}$. imperatorius patvirtino sukilimo dalyvių nuosavybės sekvestravimo taisykles. Vietos valdžiai liepta sekvestruoti sukilimo dalyvių dvarus, kitą nekilnojamąji, kilnojamąji turtą, kapitalą, vertybinius popierius bei brangiuosius metalus ir visa tai perduoti vietiniams Valstybès turto rūmams, sekvestruotus namus miestuose - vietinėms miesto valdyboms, 
kitą turtą parduoti ir už ji gautas lèšas įnešti ị iždą. Dalị nekilnojamojo turto leista palikti sukilimo nerèmusiems bendraturčiams, tačiau ịpareigojo juos dalị pajamų, priklausančių sukilimo dalyviams, reguliariai įmokèti ị iždą. Valdų nuomininkams leista likti jose tiek, kiek numatè sutartis, bet nuomą mokèti iždui. Sekvestruotų dvarų pajamas įsakyta naudoti dvarų valdymo reikalams, dengti kreditą, mokèti iždo ir žemės mokesčius, grąžinti privačias skolas. Likusias pajamas liepta padèti ị banką kaip indèlị su palūkanomis. Pažadèta, kad paaiškèjus, jog sekvestruoto dvaro savininkas kaltinamas nepagrịstai, dvaras ir likusios pajamos jam bus grąžinti [49, 5-7; 48.2]. Gubernijų Valstybės turto rūmams buvo išsiuntinèta valstybès turto ministro Aleksandro Zelenojaus instrukcija, nustatanti sekvestruotų dvarų perėmimo ị valstybės iždą, jų valdymo ir valdytojų atsiskaitymo tvarką [27, 4-5].

Sekvestruotų dvarų valdytojais rekomenduota skirti Valstybės turto rūmų valdininkus, tačiau jeigu dèl sekvestravimo masto tokių valdininkų pritrūktų, Rūmų valdytojams rekomenduota parinkti dvarų valdytojais ir kitus asmenis nepriklausomai nuo jų socialinès padèties. Savo nuožiūra jie galejo dvarus patikèti pirkliams, valstiečiams ar miestiečiams, sekvestruotų dvarų administratoriams ar ekonomams, žodžiu, bet kuriam politiškai patikimam asmeniui, išskyrus žydus. Iš pašalinių asmenų liepta reikalauti piniginio užstato, lygaus pusės metų dvaro pajamoms, taip pat patikimo laidavimo. Sekvestruotų dvarų valdytojų darbui atlyginti numatyta skirti $10 \%$ dvaro grynųjų pajamų [27, 4v]. Vietinių asmenų ịtraukimas ị sekvestruotų dvarų valdymą neturẻjo aiškios socialinės programos bruožų, tačiau rodè tendenciją Vakarų krašte remtis žemesniais socialiniais sluoksniais, priešinamais bajorijai.

Atvykęs ị kraštą gegužès mėn. M. Muravjovas paskelbtų taisyklių nepaisè ir vykdè savarankišką politiką. 1863 m. gegužès 24 d. jis paskelbè Instrukciją dèl karinio ir civilinio valdymo Vilniaus, Kauno, Gardino, Minsko, Vitebsko ir Mogiliavo gubernijų apskrityse. Jos 14-ame punkte reikalauta tuoj pat sekvestruoti dvarus ir turtą tų asmenų, kurie „prisiekè sukilèliams arba kitaip dalyvavo sukilime, arba rèmé ji pinigais ir kitais materialiniais ištekliais, platino sukilimo proklamacijas ir apskritai nepatikimais ir nusikalstamais veiksmais bandè nuversti valstybès valdžią“. Gubernatoriams liepta šią priemonę taikyti nedelsiant ir „nesvyruojant“ („не допуская ни малейшего колебания“). Nuosaikesnę 1863 m. kovo 15 d. ịsako nuostatą - rūpintis sekvestruotais dvarais, tvarkingai juos valdyti, laiku rinkti mokesčius ir jų nepriemokas ị iždą, nepalikti dvarų savininkų be pragyvenimo šaltinio - pakeitė kategoriškas reikalavimas visus sekvestruotų dvarų grūdus nusavinti kariuomenei ir kaimo sargyboms išlaikyti, kitus maisto produktus ir kilnojamąji turtą išparduoti, o gautus pinigus ir visas dvarų pajamas skirti sukilimui slopinti [26]. Ši priemonè buvo ekstraordinarinè ir laikina, neorientuota ị ilgalaikę perspektyvą.

Sekvestruoti bajorų dvarai nevirto valstybès nuosavybe, bet dvarų savininkai iš jų turèjo išsikelti. Dvaruose pagaminta produkcija, išparduotas kilnojamasis turtas sudare valstybès iždo pajamų šaltinį, todèl jų valdymas ir priežiūra prilygo valstybès materialinių interesų gynimui. Dvarą perėmusiam valdininkui per vieną mėnesį reikèjo sudaryti ir pateikti dvaro valdymo planą su išsamia jo pajamų ir išlaidų sąmata, atsiskaityti Valstybės turto rūmams, vykdyti buvusio savininko kreditinius ịsipareigojimus, mokèti jo skolas ir pan. Dvarų ūkio palaikymo išlaidas, kol bus gautas pelnas, dengė Valstybès turto rūmai. Valdytojai turèjo veikti pagal instrukciją, o biurokratizuota sekvestruotų dvarų priežiūra siekta apsaugoti dvarą nuo ūkinio bankroto. Atskirai buvo perimami dvarų miškai, ir tai juos saugojo nuo iškirtimo. Nuo dvarų ūkio buvo atskirti pramoniniai gamybos objektai. $1863 \mathrm{~m}$. vasarą valstybès turto ministras A. Zelenojus ịsakẻ visas sekvestruotų dvarų degtinès ir alaus daryklas, 
jų sandèlius perduoti vietinėms akcizo valdyboms, pavesti joms išnuomoti daryklas, o sandèliuose sukauptą produkciją realizuoti urmu [14].

Dvarų sekvestravimas Vilniaus ir Kauno gubernijose prasidejjo 1863 m. birželio viduryje, kai paaiškejo pirmieji valdžios ir sukilèlių priešpriešos rezultatai. It dvarus buvo siunčiamos vadinamosios „skrajojančios komisijos“, kurias sudare gubernijų valdybų valdininkai, apskričių policijos pareigūnai, o jei dvare buvo miškas - girininkai. Valstybės turto rūmų valdininkų pareiga buvo aprašyti dvaro kilnojamąji ir nekilnojamąji turtą ir priimti dvarą i rūmų žinią. Kauno gubernijoje veikẻ apygardiniai valstybės turto rūmų skyriai, turèję prižiūrèti sekvestruotus dvarus iki valdytojo paskyrimo [5; 12; 48.1].

Dvarų sekvestravimo mastas istoriografijoje vertinamas skirtingai. R. Jurkowskio manymu, jo apskritai neįmanoma ịvertinti, nes sekvestravimo eiga nuolat kito: vieni dvarai buvo grąžinami savininkams, kiti konfiskuojami [57, 40]. Tačiau sekvestravimas bajorams žemvaldžiams turejo rimtų pasekmių: dalis dvarų nors ir grịžo savininkams, bet tik po kurio laiko, dalị jų bajorai buvo verčiami parduoti, tad ištisos bajorų giminès neteko kitados stiprių tèvoninių dvarų. Išlikusi oficiali medžiaga vis dèlto leidžia atkurti dvarų sekvestravimo eigą ir jo pasekmes.

Iš Vilniaus gubernijos viršininko kanceliarijos ir Vilniaus gubernijos valdybos nuo birželio vidurio iki rugsèjo vidurio Vilniaus valstybės turtų rūmų valdytojui reguliariai siunčiami raštai su sekvestruotinų dvarų sąrašais rodo, kad pirmosios sankcijų aukos buvo aktyvūs sukilimo dalyviai, jo rèmèjai ir sukilèlių giminès. I sekvestruotinų dvarų sąrašus buvo ịtraukti žuvusių, suimtų ir jau ištremtų i Rusijos gilumą sukilèlių dvarai, taip pat jų tèvams ar artimiausiems giminèms priklausantys dvarai [23]. Vilniaus gubernijoje valdžia veikè operatyviai: $1863 \mathrm{~m}$. birželio-rugpjūčio mènesiais visose septyniose jos apskrityse iš viso buvo sekvestruota 317 dvarų, žemès sklypų, namų ir kilnojamojo turto, iš jų 189 objektai buvo bajorų dvarai [41]. Keliolikos dvarų sekvestravimas buvo nutrauktas nenurodžius priežasčių [15]. Tuo pat metu valdininkams teko spręsti klausimą, kaip elgtis su tais dvarais, kurių savininkai sukilime nedalyvavo, tačiau jų vaikai parėmé sukilimą ginklais. $1863 \mathrm{~m}$. rugpjūčio pradžioje $M$. Muravjovas prièmè sprendimą: tuo atveju, kai savininko vaikai turèjo paveldẻjimo teisę, jų būsimąją dalị atskirti nuo bendros nuosavybès ir šiai daliai uždèti draudimą, t. y. dvaro savininkas turèjo atiduoti iždui dali savo dvaro grynųjų pajamų [16]. 1863 m. rugsèjo-gruodžio mėnesiais 35 Vilniaus gubernijoje sekvestruoti dvarai buvo grąžinti jų savininkams, iš jų 8 dvarų daliai pajamų buvo uždètas draudimas [17].

Panaši tendencija išliko ir kitais metais. Vilniaus valstybès turto rūmų ataskaitos rodo, kad dauguma dvarų buvo sekvestruota 1863-1864 metais. $1865 \mathrm{~m}$. sausio $1 \mathrm{~d}$. ši įstaiga disponavo 131 dvaru (tais metais grąžinti savininkams dvarai ataskaitoje jau neatsispindi). 1864 m. ji prièmė dar 94 dvarus, tačiau per tą laiką 99 dvarams sekvestras buvo panaikintas [31]. 1865 m. Rūmai perèmè tik 5 sekvestruotus dvarus, 8 dvarus grąžino savininkams [32]. 1866 m. ataskaita neišliko, bet 1867 m. ataskaita rodo, kad dvarų sekvestravimas Vilniaus gubernijoje praktiškai nebevyko. Tais metais rūmai valdẻ 56 sekvestruotus dvarus, 39 grąžino savininkams [33]. 1869-1872 m. Valstybės turto valdyba turèjo tik 8 sekvestruotus dvarus, dèl kurių likimo valdžia delsè priimti sprendimą. $1874 \mathrm{~m}$. sekvestruotų dvarų Vilniaus gubernijoje apskritai nebeliko $[34,11 ; 36,26 \mathrm{v} ; 37,31 \mathrm{v} ; 38]$. Taigi galima daryti prielaidą, kad 1863-1865 m. sekvestravimas buvo taikomas 288 Vilniaus gubernijos dvarams.

Kauno gubernijoje dvarų sekvestravimas vyko ne taip sklandžiai. Čia telkèsi pagrindinès sukilèlių jègos, vyko ginkluoti susirèmimai, todèl valdininkai sunkiai judejo sukilimo apimtoje teritorijoje. Jie lankè dvarus karo padèties sąlygomis, baimindamiesi patekti ị sukilèlių rankas, 
todèl delsè vykti ị paskirtuosius dvarus, vengè atlikti pareigas, ir dalis numatytų sekvestruoti dvarų iki sukilimo pabaigos nepateko ị valstybės iždą. Pagal Kauno valstybės turto rūmų valdininkų sudarytus sąrašus, nuo 1863 m. liepos iki lapkričio mèn. pradžios Kauno gubernijoje buvo sekvestruoti 72 dvarai, tačiau ,juodasis sąrašas" turèjęs būti kur kas didesnis [18] - i jị neịtraukti 26 dvarai, minimi valdininkų ataskaitų juodraščiuose [22]. Galima prielaida, kad valdininkai gavo nurodymus sekvestruoti ir daugiau dvarų. Antai Šiaulių apskrities viršininkas rugpjūčio pradžioje rašè Kauno valstybès turto rūmų valdytojui Jakovui Butkovskiui, kad jam patikètoje apskrityje reikia sekvestruoti apie 60 dvarų, dalis jų yra stambūs, o valdininkų šiam darbui atlikti trūksta [13]. I 1864 m. kovo mèn. pradžioje sudarytą Kauno gubernijoje sekvestruotų dvarų sąrašą įtraukti 194 dvarai [20], 1864 m. balandžio mẻn. pradžios sąraše yra 151 dvaras, taip pat nurodyti jų valdytojai [21, 5-20]. Tų pačių metų spalio $1 \mathrm{~d}$. Kauno valstybès turto rūmai disponavo 154 sekvestruotais dvarais, tačiau i jų sudarytą sąrašą jau nepateko 41 dvaras, grąžintas savininkams nuo 1863 m. rugsẻjo iki $1864 \mathrm{~m}$. rugsẻjo mènesio [44]. Kauno gubernijoje dar keli dvarai buvo sekvestruoti 1864 m. lapkričio mèn. - 1866 metais [19]. Taigi šis ir kiti sąrašai rodo kintančią situaciją, tačiau galima daryti prielaidą, kad sekvestravimas per visą laikotarpị buvo taikytas ne mažiau kaip 200 Kauno gubernijos bajorų dvarų. Reikia manyti, kad po 1867 m. ir čia sekvestruotų dvarų skaičius sparčiai mažejo.

Viena priežasčių, dèl kurių mažejo sekvestruotų dvarų, buvo jų valdymo problema. Parinkdami valdytojus sekvestruotiems dvarams vietiniai biurokratai praktiškai turejjo susidurti tiek su ùkine nekompetencija, tiek su socialiniu ir tautiniu klausimu, kai dar nebuvo susiformavusi aiški valdžios nuostata. Vakarų gubernijose tarnavusių valdininkų, be savo pagrindinių pareigų, pajėgusių tvarkytis dvaruose, akivaizdžiai stigo, o jų ūkinẻ kompetencija kèlè abejonių. 1863-1864 m. valdininkams ypatingiems pavedimams buvo priskirta tik dvarų kontrolè, kartais jiems tekdavo apskrityje prižiūrèti po kelis ir keliolika dvarų [21, $5 \mathrm{v}-11]$. Jie kontroliavo dvarų pajamas iš atskirų išnuomotų ūkio objektų (smuklių, malūnų, ežerų) ir ị žemės ūkio reikalus nesikišo, bet galèjo patys išnuomoti palivarką ar žemę su sąlyga, kad tai bus politiškai patikimi asmenys ir sumokès užstatą. Tačiau jiems buvo draudžiama išnuomoti visą dvarą be gubernijos viršininko leidimo [10].

Kauno gubernijos viršininkas siūlè išeitį: dvarų administratoriais skirti valstiečių bendruomenes arba sentikius su sąlyga, kad jie mokès užstatą [6]. Siūlymas atliepè M. Muravjovo mintị pagrindiniu krašto socialiniu veikejju padaryti valstietị ir sentiki, o bajorus stumti i socialinị pakrašti [9], tačiau valstiečiai tuo metu nebuvo pasirengę prisiimti ponų dvarų valdytojų vaidmens [11].

Vietos valdžia venge skirti administratoriais vietinius bajorus, juos pripažino tik tada, kai nebuvo kitų kandidatų. Ji nepasitikejjo „lenkų kilmès“ asmenimis, net jei šie sukilime nedalyvavo, ir reikalavo paliudyti jų patikimumą. Valdžiai kẻle ittarimą ir rusų politinis patikimumas. Kai iš Vilniaus tardymo komisijos atleidus štabo rotmistrą Schmidtą pasklido gandai, kad jis administruoja kažkurị sekvestruotą dvarą, pulkininkas Božeranovas atkreipé dėmesi ì sekvestruotų dvarų valdytojus rusus, neturejjusius apskričių karo viršininkų liudijimų dèl politinio patikimumo, ir pareikalavo, kad Vilniaus valstybės turto rūmai, prieš skirdami dvarų valdytojus ar administratorius, akylai tikrintų visus kandidatus nepriklausomai nuo tautybès [11]. Tie patys reikalavimai kelti dvarų nuomininkams.

Jau 1863 m. rudenị apsižiūrèta, kad sekvestruoti dvarai ir nekilnojamasis turtas Valstybès turto rūmams yra nerentabili našta: dvarų nuoma vieneriems metams nebuvo pelninga, ji nepadengè valdymo ir kitų išlaidų, o dvarų ūkis smuko. Matyt, todèl buvo nutarta diferencijuoti asmenis pagal jiems inkriminuojamą kaltę ir paskirtą bausmę. Krašto viršininkai gavo 
M. Muravjovo nurodymą sekvestruoti dvarus tik tų asmenų, kuriuos teismas atidavė ị kareivius, taip pat ištrèmè ị tolimas gubernijas, atėmè luomo teises ir skyrẻ katorgą. Ištremtụjų administracine tvarka dvarus jis siūlè ne sekvestruoti, bet skirti prasikaltusiems nuo $10 \%$ iki 50 \% baudą [7]. Po metų dèl per didelio sekvestruotų dvarų skaičiaus M. Muravjovas apkaltino gubernatorius ir karo viršininkus, kurie nepagrịstai sekvestravo dvarus tuo atveju, kai kaltinamiems prisidejus prie sukilimo buvo skirtos baudos, policijos priežiūra ar dvarų savininkams buvo skirta kontribucija. Jis nutarẻ grąžinti dalị sekvestruotų dvarų, pareikalavo tikslių duomenų apie Valstybès turto rūmų prižiūrimus dvarus, dalị jų grąžino savininkams [2]. 1865 m. balandžio mèn. generalgubernatoriaus padejjejjas ịsteigè komisiją, kuriai buvo pavesta apsvarstyti ištremtų politiškai nepatikimų asmenų sekvestruoto turto klausimą ir sumažinti sekvestruotaji turtą [3].

Dalis sekvestruotų dvarų savininkams nebegrị̌zo. Jų likimą lėmė Ypatingosios komisijos, kuriai vadovavo Ministrų komiteto pirmininkas P. Gagarinas, nutarimas, priimtas atsižvelgiant ị naujo Vilniaus generalgubernatoriaus K. Kaufmano siūlymus ịpareigoti sekvestruotų dvarų ir iš krašto ištremtų sukilimo dalyvių dvarų savininkus per dvejus metus iki $1867 \mathrm{~m}$. gruodžio $10 \mathrm{~d}$. savarankiškai parduoti nuosavybę stačiatikiams rusams arba protestantams. Pasibaigus nustatytam terminui, neparduotus dvarus liepta parduoti iš varžytinių, neatsiradus pirkejuc - perimti ị valstybès iždą, o buvusiems savininkams mokèti metinę 5 \% rentą. Šis nutarimas buvo ịtrauktas ị 1865 m. gruodžio 23 (10) d. ịsaką [66, 179-181].

Remiantis Vilniaus generalgubernatoriaus potvarkiu buvo surinkti duomenys apie privalomai parduotinus dvarus. Jų sąrašus, kuriuose nurodytas savininkas ir apytikslis dvaro žemių plotas, 1866 m. išspausdino Vilniaus gubernijos valdybos spaustuvè. Paskelbti sąrašai rodo, kad Vilniaus gubernijoje reikejo privalomai parduoti 111 dvarų (95 savininkai), iš viso 146497 deš. žemės ( 1 deš. = 1,09254 ha), iš jos 44330 deš. (įskaitant miškus) priklausè grafui Jonui Tiškevičiui. Kauno gubernijoje numatyta parduoti 121 dvarą (114 savininkų), iš viso 59773 deš. žemès [52; 53]. Dauguma šių dvarų priklausẻ iš krašto ištremtiems bajorams [plg. 50; 51], tad jie buvo parduoti arba atiteko valstybès iždui. Itin retais atvejais parduoti dvarai grižždavo buvusiems savininkams. Antai 1873 m. Aleksandras II sugrąžino Jonui Tiškevičiui visus jo išparduotus dvarus [29]. I privalomai parduotinų dvarų sąrašą nepatekę sekvestruoti dvarai grižo savininkams, kai pagal $1867 \mathrm{~m}$. gegužès $7 \mathrm{~d}$. imperatoriaus įsaką nebaigtos sukilimo dalyvių bylos, išskyrus pripažintųjų sunkiais nusikaltèliais, buvo nutrauktos [4].

Sukilimo dalyvių dvarai buvo konfiskuojami remiantis Karinio baudžiamojo kodekso I dalies 176 straipsniu, kuris skelbè, kad pasienio gubernijose sukilusiems taikoma ne tik bausmė, bet ir turto konfiskacija [49, 1-2], trukusi beveik dešimtmetį. Per vykusią akciją konfiskuotų dvarų statusas ir skaičius nuolat kito: dalis dvarų buvo parduota, dalis perkvalifikuota ì sekvestruotus, dalis grị̌o savininkams. Be to, vieni dvarai buvo konfiskuojami visi, kitų dvarų nusavinta tik ta dalis, kuri priklausè ištremtam ar žuvusiam sukilèliui, dèl to konfiskacija vyko lètai, dvarą reikejjo aprašyti ir padalyti nuosavybę.

Kaip keitėsi konfiskuotų dvarų statistika Vilniaus gubernijoje, rodo Valstybès turto rūmų / valdybos ataskaitos. $1863 \mathrm{~m}$. dvarų konfiskavimas apskritai nevyko. $1864 \mathrm{~m}$. buvo konfiskuoti 57 dvarai, iš jų 29-ių - tik dalis, 1865 m. Rūmai disponavo 91 konfiskuotu dvaru, iš jų 47-ių perimta tik dalis. $1867 \mathrm{~m}$. šis skaičius nebuvo pakitęs, bet tais metais buvo konfiskuoti dar 4 dvarai, o 5 dvarai buvo grąžinti savininkams, valdyboje liko 90 konfiskuotų dvarų, iš jų 59-ių - tik dalis. Iki 1874 m. konfiskuotų dvarų skaičius mažai keitėsi. Nedidelè dalis dvarų buvo parduota - visas dvaras arba padalijus jị sklypais, keli dvarai grąžinti savininkams [31-37]. Duomenų apie Kauno gubernijoje konfiskuotus dvarus yra ne už visą 
aptariamąji laikotarpị. Yra žinoma, kad 1864 m. spalio 1 d. - 1864 m. gruodžio 18 d. Kauno gubernijoje buvo konfiskuoti 96 dvarai [43]. 1866 m. vasario 4 d. duomenimis, Kauno gubernijos valstybès turto valdyba prižiūrẻjo 57 konfiskuotus dvarus, iš jų 22-ų dvarų buvo konfiskuota tik dalis [40].

Visi konfiskuoti dvarai turèjo būti vienaip ar kitaip parduoti, tačiau dèl vykdomos valstiečių reformos, ̣̂vairių teisinių ir biurokratinių procedūrų šis procesas užsitęsè.

1863 m. sukilimo dalyvių dvarų konfiskavimo bylos Vakarų gubernijose buvo nutrauktos, kai imperatorius patvirtino $1873 \mathrm{~m}$. gegužès $11 \mathrm{~d}$. Ministrų komiteto nutarimą baigti visas senas turto konfiskavimo bylas ir nepradèti naujų [48.3]. $1874 \mathrm{~m}$. vasario $3 \mathrm{~d}$. Ministrų komiteto nutarimu patikslinta, kad dvarų konfiskavimas panaikinamas, jeigu bylos nebaigtos nagrinèti iki 1873 m. gegužès 11 d., o iki 1874 m. nebuvo baigta teisinè dvarų peremimo procedūra ir galutinai neatiteko valstybės iždui, taip pat tais atvejais, jeigu dèl jų nebuvo specialaus sprendimo. Dvarus leista grąžinti savininkams, tačiau su sąlyga, kad dèl to nenukentès trečiųjų asmenų, pvz., kreditorių, interesai, grąžintų dvarų savininkai nereikš jokių pretenzijų ir nereikalaus grąžinti per konfiskavimo laiką surinktas ị iždą dvarų pajamas [48.4]. Vilniaus gubernijos valstybès turto valdybos $1874 \mathrm{~m}$. ataskaita rodo, kad tais metais savininkams sugrąžinti 42 dvarai, 1876 m. valdybos žinioje liko 15 konfiskuotų dvarų [38, 39].

\section{RUSŲ DVARININKUৃ GRUPĖS SUSIDARYMAS. ŽEMĖVALDOS VEIKSNYS}

Turtinių sankcijų taikymas sukilimo dalyviams buvo instrumentinio pobūdžio ir negalejo pakirsti bajorų žemvaldžių pozicijos Vakarų krašte. Pagal valdžios sumanymą tai turèjusi padaryti socialinè ir tautinè opozicija, kuriai sukurti buvo panaudotas žemévaldos veiksnys. M. Muravjovo idejja performuoti krašto socialinę struktūrą ir vietos bajorų socialiniu konkurentu paversti valstiečius [63; 70] buvo igyvendinama visą XIX a. antrąją pusę.

Rusų žemvaldžių kolonizacija siekta suformuoti elitinę rusų dvarininkų grupę, priešinamą vietos dvarininkams. Tikètasi, kad ji užims vyraujančias pozicijas krašto bajorų luomo struktūroje, biurokratiniame aparate, taps režimo atrama igyvendinant savivaldos ir teismų modernizacijos reformas. Šią idejją optimistiškai suformulavo Vilniaus generalgubernatorius K. Kaufmanas, rusų dvarininkų žemėvaldos įdiegimo Vakarų krašte projekte nutapęs idealų elitinio ruso kolonisto paveikslą: „[rusų dvarininkai] norès pirkti dvarus Šiaurès vakarų gubernijose, jie atsiveš i kraštą ne tik savo šeimas, bet ir tarnus, galiausiai dauguma jų patrauks paskui save ir valstiečius, todèl visi, Šiaurès vakarų gubernijose ịsigiję dvarų, paklos ištisos rusų gyvenvietès pamatus, pasodins Lietuvos žemėje stačiatikybès krūmą. Neverta nẻ kalbèti apie moralinę įtaką, kurią krašte darys, pvz., 10-12 rusų dvarininkų, apsigyvenusių vienoje apskrityje. Taip pat nekalbant apie tai, kad jie bus paspirtis vietos valdžiai, vykdančiai vyriausybès nurodymus, nes jie sudarys pasirengusị ir sėslųji elementą, tinkamą žemietijoms, iš dalies ir teismų reformai, jie bus patikimas stačiatikybès plètros ir įsišaknijimo krašte laidas, jie atsineš ir išvystys rusišką liaudiškumą ir palaikys liaudies mokyklas, suteikdami joms rusišką kryptị “ [63, išnaša Nr. 39].

Pirmieji žingsniai, atvedę ì kraštą rusų žemvaldžius kolonistus, buvo nukreipti ị stiprių rusų žemvaldžių grupès sudarymą ne itin paisant jų socialinės kilmès. Valstybės turtų ministro A. Zelenojaus pasirašyti $1864 \mathrm{~m}$. kovo $5 \mathrm{~d}$. nuostatai „Apie lengvatas, privilegijas ir paskolas perkantiems valstybinius ir privačius dvarus Vakarų gubernijose“ numatẻ lengvatines sąlygas valstybinių ir iš varžytinių už skolas parduodamų dvarų, taip pat „lenkų kilmès“ dvarininkų savo noru parduodamų dvarų pirkèjams. Galima pirkèjų kategorija buvo apibrèžta kaip visos imperijos ir visų luomų gyventojai, svarbu - „ne lenkų kilmès“ ir ne žydai. Jiems buvo 
suteikta teisè i $6 \%$ paskolą, įskaitant dvaro skolą valstybei, grąžinamą per 37 metus. Pirmos ir antros gildijų pirkliams, ịsigijusiems dvarą be paskolos už ne mažiau kaip 15 tūkst. rb arba sutikusiems sumokèti dvaro skolą, siekiančią ne mažiau kaip 30 tūkst. rb, arba įsigijusiems dvarą už paskolą buvo pažadètas paveldimo garbès piliečio vardas. Tačiau nuostatai numatė pinigines ir teisines sankcijas nemokiems paskolos gavejjams, taigi jie nebuvo apdrausti nuo issigyto dvaro atėmimo ir pardavimo iš varžytinių. Be to, jiems buvo uždrausta ịsigytus dvarus parduoti, nuomoti arba perduoti valdyti lenkams ir žydams. Pastariesiems leista išnuomoti tik degtinès varyklas ir smukles. Norint gauti paskolą, neviršijančią pusès dvaro vertès, reikẻjo generalgubernatoriaus tarpininkavimo ir valstybès turto ministro leidimo [49.1]. Šie nuostatai buvo pagrịsti ne ekonomine, bet politine prielaida. Kliovimasis tautiškumo veiksniu iš anksto apribojo žemės apyvartos galimybes vidaus rinkoje. Be to, jie nesuteikè potencialiems kolonistams rimtesnių garantijų savo rankose išlaikyti ịsigytus dvarus.

Rusų dvarininkų kolonizacijos plètrai turèjo padèti istoriografijoje plačiai aptarta $1865 \mathrm{~m}$. liepos 23 d. instrukcija, kurią parengè Ministrų komitetas, atsižvelgęs ị M. Muravjovo siūlymus sudaryti lengvatines sąlygas ịsitvirtinti Vakarų krašte tarnaujantiems karininkams ir valdininkams, pageidavusiems čia pasilikti, taip pat kitiems patikimiems rusų kilmès asmenims, kurie panorès apsigyventi krašte. Jiems buvo leista pirkti laisvai, ne iš varžytinių, valstybinius dvarus, fermas, žemę ir nekilnojamąji turtą mieste. Pardavimui skirtas fondas turejo būti sudarytas iš laisvų valstybinių žemių, taip pat iš konfiskuotų vietinių bajorų dvarų, galutinai perimtų $\mathfrak{i}$ valstybès iždą. Orientaciją $\mathfrak{i}$ vidutinị ir stambesnị pirkèją rodè pardavimui skirtų sklypų dydis: 300-600, 600-1 000 deš., o ypatingais atvejais ir daugiau. Kartu su žeme turèjo būti parduodami ūkiniai pastatai ir atskirai nuomojamos ūkio šakos. Konfiskuoti dvarai su stambiomis gamyklomis ar fabrikais ị dalijamų sklypų kategoriją nepateko. İsivaizduojamas dvarų pirkejjas tai - Vakarų krašte civilinę (ne karo) tarnybą atliekantys karininkai ir valdininkai „ne lenkai“, taip pat rusai, nusipelnę valstybės tarnyboje ar visuomenineje veikloje ir pageidaujantys persikelti gyventi ị Vakarų kraštą. Kitaip tariant, pagal šios instrukcijos taisykles dvarą galejo įsigyti asmenys, priskirtini elitiniams visuomenès sluoksniams. Tačiau ir ị šią kolonistų kategoriją žiūrèta selektyviai: jų uolią tarnybą ir politini patikimumą turëjo paliudyti jų tiesioginiai viršininkai. Didesnio kaip 600 deš. dvaro galèjo tikètis tik laikomi itin naudingais kraštui asmenys. Pirkliai ir miestiečiai galèjo pretenduoti tik į nekilnojamąją nuosavybę mieste.

Pirkẻjams suteikiamos lengvatos priklausè nuo jų tarnybinių nuopelnų. Atlyginimas už gerą tarnybą buvo leidimas pirkti dvarą ar namą mieste be užstato, visą pirkinio sumą išmokèti per 20 metų be palūkanų, taip pat nemokèti pirkimo ir pardavimo sutarties mokesčio. Kitiems pirkẻjams suteikta galimybė mokèti už įsigytą dvarą 37 metus su $6 \%$ palūkanomis. Paskolos ar lengvatų suteikimas buvo susijęs su rizika. Visą teisę ị dvarą savininkas galejo igyti tik visiškai atsiskaitęs už pirkinị. Laiku nesumokèjęs paskolos ir palūkanų pirkèjas rizikavo netekti ne tik dvaro, bet ir visų buvusių imokų. Instrukcija dar kartą patvirtino naujiems dvarų savininkams ir jų paveldètojams numatytą draudimą parduoti, dovanoti, perleisti, įkeisti ar nuomoti dvarus lenkams ir žydams. Atrinkti potencialius pirkejjus buvo pavesta generalgubernatoriams ir valstybès turto ministrui, tačiau galutinị žodị turejjo tarti imperatorius. Ta pati leidimų tvarka galiojo, jeigu dvaro pirkejjas vèliau ketintų parduoti įsigytą dvarą, bet tik rusų kilmės asmeniui [49, 37-44]. Vykdydamos šią instrukciją vietos valdžios institucijos susidūrè su praktinèmis kliūtimis, pirmiausia - ribota galimybe iš disponuojamo žemès fondo suformuoti reikiamo dydžio sklypus. Todèl $1867 \mathrm{~m}$. balandžio $24 \mathrm{~d}$. Valdančiojo Senato įsakas leido formuoti mažesnius sklypus (50-300 deš. ir 20-50 deš.) ir 
juos tomis pačiomis lengvatinėmis sąlygomis parduoti smulkesniems tarnautojams rusams: iki 300 deš. sklypai buvo skirti Vakarų krašte tarnaujantiems ir politiškai patikimiems valdininkams, o smulkūs sklypai - labiausiai pasižymėjusiems kaimo liaudies mokyklų mokytojams ir valsčių raštininkams [49, 90-91].

Itin reikšmingas žingsnis, turèjęs sustiprinti rusų dvarininkų poziciją krašte, buvo 1865 m. gruodžio $10 \mathrm{~d}$. Valdančiojo Senato ịsakas, uždraudęs lenkų kilmès asmenims ịsigyti naujų dvarų devyniose Vakarų krašto gubernijose. Tuo pačiu įsaku reikalauta parduoti rusų kilmès asmenims, stačiatikiams ar protestantams, sekvestruotus ir nesekvestruotus ištremtų iš krašto sukilimo dalyvių dvarus arba juos apkeisti ị dvarus kitose imperijos gubernijose [49, 48-50]. Siekiant geresnių rezultatų ir užtikrinti akcijos vykdymo kontrolę, visų Šiaurès vakarų krašto dvarų pardavimas buvo pavestas Vilniaus gubernijos valdybai [49, 92].

Reikia pasakyti, kad rusų valdininkų, norinčių tuoj pat lengvatinėmis sąlygomis įsigyti konfiskuotus sukilèlių dvarus, netrūko. Pirmiausia tų, kurių darbas buvo tiesiogiai susijęs su žemètvarka. Jie net bandè, apeidami ịstatymus, išsinuomoti nusižiūrètą dvarą iki gaus leidimą jị îsigyti [24].

Tačiau užduoties suformuoti rusų dvarininkų žemèvaldą igyvendinimas susidūrè su kliūtimis, kurios iš esmès lètino kolonizacijos plètrą ir tempą. Jos pradžia sutapo su valstiečių reformos vykdymu, todèl vietos administracijai vienu metu teko spręsti žemèvaldos ir žemėnaudos problemas. Tam, kad būtų suformuoti pardavimui tinkami sklypai konfiskuotuose dvaruose, daugumą jų reikejjo padalyti tarp valstybės ir dvarų bendraturčių arba paveldètojų, atsiskaityti su dvarų savininkų kreditoriais. Dalies konfiskuotų dvarų skolos viršijo jų nustatytąją vertę, o tokiais atvejais generalgubernatorius reikalavo dvarą parduoti tik iš varžytinių. Nors valdžia disponavo šiokiu tokiu valstybinių žemių fondu (pvz., $1866 \mathrm{~m}$. sausio pradžioje Kauno gubernijoje buvo 52 neišnuomotos ir 36 dvylikai metų išnuomotos fermos (apie 17 tūkst. deš.), taip pat 20 tūkst. deš. laisvų ganyklų ir šienaujamų pievų), liustracijos komisijoms buvo liepta skirstant žemę nepažeisti valstiečių interesų, todèl, kol liustracijos darbai nebuvo baigti, sklypai iš konfiskuotų dvarų žemių buvo formuojami lètai [8]. Norèdamas paspartinti šiuos darbus K. Kaufmanas liustracijos komisijoms liepè vertinti tik tuos konfiskuotus dvarus, kuriuose žemę atidalijus valstiečiams liko daugiau kaip 1000 dešimtinių. Smulkesniuose dvaruose jis leido parduodamus sklypus sudaryti taikos tarpininkų suvažiavimams ir tikrinimo komisijoms [1;42], tačiau tai nedave apčiuopiamų rezultatų.

Rusų dvarininkų žemèvaldos susidarymo tendencijos 1866-1873 m. išsamiai aptartos Vilniaus generalgubernatoriaus Aleksandro Potapovo ataskaitose apie padètị jam pavaldžiose gubernijose. 1866-1870 m. ataskaitoje buvo pateikti duomenys apie Vilniaus, Kauno, Gardino ir Minsko gubernijas. Šiais duomenimis, $1870 \mathrm{~m}$. rugsėjo $1 \mathrm{~d}$. minètose gubernijose 2097 vietiniai dvarininkai valdè 2371488 deš. žemès (iš jų Vilniaus gubernijoje 399 dvarininkai valde 339713 deš., Kauno gubernijoje 505 dvarininkams priklause 389717 deš. žemès) ir tik 493 rusų kilmès pirkejjai jose įsigijo 354358 deš. žemès. Didžiausią paklausą turèjo vadinamieji „instrukciniai“ dvarai ir žemès sklypai. Keturiose gubernijose tokių dvarų (iš viso 146334 deš. žemès) įsigijo 373 pasižymejję tarnyboje valdininkai, tarp jų Vilniaus gubernijoje 28980 deš. žemės pirko 94 asmenys, Kauno gubernijoje 18035 deš. žemès pirko 52 asmenys. Be to, keturiose gubernijose dar 22 asmenys savo iniciatyva pirko 18096 deš. žemès. Tiesiai iš savininkų buvo nupirkti 124 privalomai parduodami dvarai (Vilniaus gubernijoje - 33 dvarai su 102509 deš. žemès, Kauno gubernijoje - 52 dvarai su 58530 deš. žemès), iš varžytinių buvo parduoti 98 privalomai parduodami dvarai su 46262 deš. žemès (iš jų Vilniaus gubernijoje parduota 30 dvarų su 11615 deš., Kauno gubernijoje parduoti 37 dvarai su 14370 deš. žemès) 
[28.1]. 1871-1873 m. dvarų pardavimo tendencijos liko tos pačios. Per tą laiką Vilniaus, Kauno ir Gardino gubernijose 212 rusų žemvaldžių issigijo 110446 deš. žemès: Vilniaus gubernijoje - 32385 deš. (79 asmenys), Kauno gubernijoje - 33562 deš. (71 asmuo). Kaip ir anksčiau, tai buvo „instrukciniai“ ir privalomai parduodami dvarai, ịsigyti lengvatinèmis sąlygomis tiesiai iš savininkų arba iš varžytinių [29].

A. Potapovo manymu, tokia padetis reiškè, kad per devynerius rusų žemvaldžių kolonizacijos metus vyriausybès tikslai, susiję su priverstiniu žemėvaldos perskirstymu Vakarų krašte, pasiekti nebuvo. Ši teigini jis pagrindè statistikos duomenimis, kurie rodo, kad $1873 \mathrm{~m}$. Vilniaus, Kauno ir Gardino gubernijose 11581 „lenkų kilmès“ žemvaldžiui (ataskaitoje pabrèžta, kad išskyrus valstiečius) priklausẻ 3480729 deš. žemès, o „ne lenkų kilmès“ 1299 žemvaldžiams priklausė 1088079 deš. žemės [29.1]. Ženkliai išaugęs tiek lenkų, tiek „ne lenkų“ žemvaldžių skaičius ir jiems priklausančios žemès plotas, palyginti su $1870 \mathrm{~m}$. duomenims, gali būti paaiškintas tuo, kad pirmoje ataskaitoje buvo pateikti duomenys tik apie dvarininkus, o antrojoje ị ši skaičių buvo ịtraukti dvarininkai, smulkių žemės sklypų savininkai ir sklypų miestuose savininkai. Tačiau tai tik prielaida, nes ataskaitoje nėra paaiškinimų, kaip buvo sudaryti duomenys. Matyt, taip pateikta statistika turejo sušvelninti neigiamas išvadas apie rusų dvarininkų kolonistų pasyvumą: nors šiose trijose gubernijose „ne lenkai“ sudarè $10 \%$ visų žemès savininkų, jiems vis dèlto priklausė 23,8 \% žemès.

Socialinis ir tautinis eksperimentas, turèjęs „radikaliai pakeisti krašto žemvaldžių luomo sudètị $[66,180]$, pirmajame jo igyvendinimo etape nepavyko. A. Potapovui ir ataskaitas rengusiai jo aplinkai šio kuklaus rezultato priežastys buvo rimtos ir nevienareikšmés. Jie objektyviai vertino XIX a. 7-ajame dešimtmetyje imperijoje vykusias permainas. Tai buvo ekonominès, techninès, socialinès ir kultūrinès imperijos modernizacijos laikotarpis. Ataskaitos rengejjai pabrèžè, kad valstiečių, savivaldos, teismų ir kitoms reformoms reikèjo didelių ekonominių, kapitalo ir žmogiškųjų išteklių, todèl vargu ar atsiras pakankamai žmonių, „pasirengusių savo verslumą ir kapitalą panaudoti ne imperijos centre, bet ekonomiškai nualintuose pakraščiuose, persikelti i priešišką ar bent jau svetimą aplinką“. Potencialiais dvarų pirkejjais galejo būti tik asmenys, „čia atvykę visai dèl kito tikslo“, t. y. tie, kurie atvyko malšinti sukilimą, administruoti kraštą, vykdyti valstiečių reformą ir rusifikuoti krašto gyventojus. Ataskaitos rengejjai teigè, kad dvarams supirkti atsiųstų valdininkų gal būtų pakakę, bet jie neturèjo lèšų nei dvarui pirkti, nei ūkiui plètoti, o vietos dvarininkai stengèsi neišleisti dvarų iš savo rankų, solidariai remdami pašlijusių dvarų savininkus finansiškai, atidėdami skolų mokejimo terminus ir pan., todèl varžytinès ar laisvas pardavimas buvo neefektyvi dvarų pardavimo forma. Nedaug žmonių pasinaudojo specialių i̦statymų numatytomis lengvatomis ir paskolomis. Valstybès iždas nutraukẻ paskolų teikimą, ìvairios institucijos dèl skirtingų priežasčių atsisakè atidèti iždo skolų mokèjimo terminus, nepasiteisino trumpai veikusi privati kredito institucija, lěšų pritrūkusi Dvarų pirkejjų Vakarų gubernijose draugija (Товарищество приобретателей имений в Западных губерниях). Pirkejjai rusai, net įsigiję dvarus itin palankiomis sąlygomis, retai galejo gauti tvarkingą ir ùkiškai rentabilų dvarą, todèl jam atkurti reikejjo papildomų investicijų. Retas naujasis dvarininkas galejo pasisamdyti tinkamą dvaro valdytoją: samdyti lenką, išmaniusị dvaro ūkị, draude įstatymas, valdytojų rusų Vakarų kraštas neviliojo, samdyti užsienietị galèjo tik labai turtingas dvarininkas. Be to, dažną būsimą kolonistą neviliojo perspektyva netekti dvaro ir i ji i̇dètų lèšu laiku neatsiskaičius už paskolą, skolas ir mokesčius [28].

1869 m. vietos administracija ragino naujuosius krašto žemvaldžius rusus įsirašyti į apskrities, kurioje pirko dvarą, bajorų genealogijos knygas, kad ateityje galètų pretenduoti i 
renkamąją tarnybą. Ta proga apskričių policijos valdybos rinko duomenis, kuriuos apskričių bajorų vadovai teikẻ gubernijos administratoriams. Duomenys buvo pateikti ne visi, rinkti atmestinai, vadovaujantis skirtingais kriterijais: vieni pateikè duomenis apie dvarininkus rusus, kiti - apie dvarininkus „ne lenkų kilmès“. Antai Kauno gubernijoje buvo sudarytas 86 rusų žemvaldžių sąrašas, iš jų penkių giminès Lietuvoje ịsikūrẻ XIX a. pradžioje, kiti - krašte tarnavę atsargos karininkai, įvairių rangų valdininkai, du pirkliai, septynios moterys (dauguma jų valdininkų našlès) [45; 46].

Vilniaus gubernatoriaus kanceliarijoje buvo sudarytas išsamesnis Vilniaus gubernijos „ne lenkų kilmès“ žemvaldžių, tarp kurių ịrašyti rusai, sąrašas. Jo duomenys rodo, kad gubernijoje susidarè nedidelè „lenkų kilmès“ bajorams priešpriešinama žemvaldžių grupè, turejjusi skirtingų konfesinių, tautinių ir socialinių bruožų.

1 lentelè. „Ne lenkų kilmės“ žemvaldžių pasiskirstymas pagal konfesiją Vilniaus gubernijoje 1864-1870 m.

\begin{tabular}{|c|c|c|c|c|c|}
\hline Apskritis & Stačiatikiai & Evangelikai liuteronai & Evangelikai reformatai & Musulmonai & Iš viso \\
\hline Vilniaus & 45 & 8 & 3 & 20 & 76 \\
\hline Ašmenos & 31 & 6 & 1 & 26 & 64 \\
\hline Dysnos & $32^{*}$ & - & 1 & - & 33 \\
\hline Lydos & 34 & 9 & 3 & 17 & 63 \\
\hline Traku & 38 & 8 & 1 & 32 & 79 \\
\hline Švenčionių & 23 & 4 & 1 & 10 & 38 \\
\hline Vileikos & 33 & 3 & 3 & 8 & 47 \\
\hline Iš viso & 236 & 38 & 13 & 113 & 400 \\
\hline
\end{tabular}

Šaltinis: [25; 47]. * Iš jų vienas sentikis. Lentelèje nurodytas dvarų savininkų skaičius iš tikrujų buvo mažesnis. Savininkai, turèję dvarų keliose apskrityse, lentelèje nurodyti po kelis kartus.

Daugumą „ne lenkų“ kilmės žemvaldžių sudare stačiatikiai, priskiriami rusų kilmès žmonių kategorijai. Tarp jų pateko ir tie, kurie atsivertė ị stačiatikybę, tikèdamiesi išvengti vietiniams bajorams taikomų apribojimų žemėvaldos srityje, pvz., Dysnos apskrities Čeresų dvaro savininkas Mykolas Radvila [47, 75] arba tos pačios apskrities Uzmėnų dvaro savininkas Edmundas Oginskis, ar Tadulino ir Belobrodės dvarų savininkè Ignoto Lopacinskio našlė $[47,76]$ ir kt. Kita stambesnè „ne lenkų“ žemvaldžių grupé - Lietuvos totoriai, kuriems nebuvo taikomas $1865 \mathrm{~m}$. gruodžio 10 d. ịstatymas. Socialiniu požiūriu daugumą žemès savininkų sudarè bajorai ir stambūs bei smulkūs rusų valdininkai, kurių socialinè kilmè nèra aiški, keletas miestiečių ir du pirkliai.

2 lentelè. „Ne lenkų kilmės“ žemvaldžių dvarų ir i sigigytų žemės sklypų dydis Vilniaus gubernijoje 1864-1870 m.

\begin{tabular}{|c|c|c|c|c|c|c|c|c|c|}
\hline \multirow{2}{*}{ Konfesija } & \multicolumn{8}{|c|}{ Dešimtinės } & \multirow{2}{*}{$\begin{array}{l}\text { Iš viso } \\
\text { dvarų }\end{array}$} \\
\hline & iki 50 & $51-200$ & $201-400$ & $401-600$ & $601-800$ & $801-1000$ & $1001-2000$ & Virš 2000 & \\
\hline Stačiatikiai & 22 & 81 & 62 & 34 & 13 & 13 & 29 & 15 & 269 \\
\hline $\begin{array}{c}\text { Evangelikai } \\
\text { liuteronai }\end{array}$ & 4 & 8 & 10 & 3 & 1 & & 7 & 9 & 42 \\
\hline $\begin{array}{l}\text { Evangelikai } \\
\text { reformatai }\end{array}$ & & & 2 & & 1 & 1 & 8 & 7 & 19 \\
\hline Musulmonai & 45 & 54 & 9 & 1 & 4 & & 1 & 1 & 115 \\
\hline Iš viso & 71 & 143 & 83 & 38 & 19 & 14 & 45 & 32 & 445 \\
\hline
\end{tabular}

Šaltinis: [25, 47]. Dvarų ir savininkų skaičius 1-2 lentelèse nesutampa, nes vienam savininkui galejo priklausyti keli dvarai, be to, pateikti skirtingi duomenys apie vienam savininkui priklausančių kelių dvarų žemės plotą: nurodomas bendras plotas arba pagal atskirus dvarus. 
Pagal žemėvaldos dydị dauguma rusų žemvaldžių priklausė vidutiniam sluoksniui, bet buvo ir stambių žemvaldžių. Tarp jų, ko gero, daugiausia žemių supirko atsargos generolas Dmitrijus Mavrosas, įsigijęs kelis dvarus Lydos apskrityje ir Kaltanėnų dvarą Švenčionių apskrityje, iš viso per 10 tūkst. deš. žemès [47, 83, 88]. Tarp evangelikų reformatų (dauguma jų buvo senieji vietiniai žemvaldžiai) išsiskyrẻ vienas stambiausių krašto žemvaldžių Petras Vitgenšteinas, kuriam priklausẻ daugiau kaip 130 tūkst. deš. žemès Ašmenos, Dysnos, Trakų, Vileikos ir Vilniaus apskrityse [47, 68, 76, 83, 91]. Tarp liuteronų tikèjimo žemvaldžių minėtinas generalinis konsulas Rygoje Kristijonas (Christianas) Vermanas, ịsigijęs tris dvarus Vilniaus apskrityje ir Valažino miestelị Ašmenos apskrityje, iš viso daugiau kaip 44 tūkst. dešimtinių $[47,71,93]$. Dauguma totorių musulmonų priklausė smulkiųjų žemvaldžių kategorijai, o savo turtą paveldejjo; retas jų XIX a. antrojoje pusejje pirko stambų dvarą, kaip tai padarė Lenkijos Karalystės Kališo gubernijos valdybos patarėjas Dovydas Bazarevskis, Ašmenos apskrityje nusipirkęs Bonifacovo dvarą [47, 91], ir Bergeliškių bei Kutų savininkas atsargos majoras Machmetas Achmatovičius, toje pačioje apskrityje įsigijęs ir Tetiuchovščiznos dvarą $[47,93]$. Taigi „ne lenkų“ žemvaldžių grupe buvo mišri, pusę jos sudarè naujieji kolonistai.

\section{IŠVADOS}

Po 1863-1864 m. sukilimo Rusijos imperijos politikoje Šiaurès vakarų krašto atžvilgiu ypatingą vaidmenị vaidino žemėvaldos veiksnys. Privati žemės nuosavybė buvo reguliuojama politinėmis represinėmis priemonėmis mažiausiai paisant ekonominių tikslų. Represijų ir spaudimo žemévaldos srityje objektas pirmiausia buvo krašto smulkieji, vidutiniai ir stambieji bajorai žemvaldžiai. Siekdama įveikti didžiausią savo konkurentą kovoje dèl įtakos krašto visuomenei imperijos valdžia paskelbè, pasak D. Beauvois, „kovą dèl žemès“, kurioje naudojo politines, socialines, tautines ir ekonomines priemones. Ši kova tęsèsi iki Rusijos imperijos žlugimo. Per visą XIX a. antrąją pusę - XX a. pradžią imperija stengèsi išstumti bajorus žemvaldžius iš dvarų, keisdama taktiką, metodus ir instrumentus.

Pirmasis šios kovos dèl žemès etapas truko 1863-1873 metais. Šiuo laikotarpiu susiformavo aiški imperinės politikos strategija ir kryptis: pakirsti vietos elito jègas, sukurti stiprią socialinę ir tautinę / konfesinę atsvarą, pajègią išstumti vietos elitą iš svarbiausių pozicijų visuomenèje. Šiuo laikotarpiu dèl daugybès priežasčių nebuvo igyvendinta M. Muravjovo vizija pakeisti krašto socialinį veikèją, atsiremti į vietinị ir atkeltą rusų valstietį. Daug vilčių dèta ị bajorų luomo, pirmiausia žemvaldžių, sudèties transformaciją. „Lenkų kilmès“ bajorus žemvaldžius turèjo ne tiek pakeisti, kiek atsverti „naujieji dvarininkai“, pageidautina rusų kilmès ir stačiatikiai, bet jais galejo būti ir protestantai. „Lenkų kilmès“ dvarininkams taip pat buvo priešpriešinami bajorų luomui priklausę krašto senbuviai evangelikai liuteronai, evangelikai reformatai ir totoriai musulmonai. Kilminių bajorų žemvaldžių luominę struktūrą turèjęs griauti „naujųjų dvarininkų“ socialinis modelis: jais galejo tapti įvairios kilmès ị kraštą atsikèlę stambieji ir smulkieji valdininkai (bajorai, dvasininkų vaikai, „raznočincai“), pirkliai ir miestiečiai, atitinkantys tautinius ir politinio patikimumo kriterijus.

Pirmojo etapo rezultatai buvo nevienareikšmiai. Nors turtinių sankcijų taikymu 1863$1864 \mathrm{~m}$. sukilimo dalyviams nesiekta sužlugdyti bajorų luomo, dvarų sekvestravimas ir konfiskavimas taikė i bajorų elito egzistencini pamatą. Privalomai parduodant sekvestruotus dvarus iš vietos bajorų rankų slydo tèvonijos, jų praradimo mastas nematuotinas skaičiais. Paveldimų dvarų perèjimas i „naujųjų dvarininkų“ rankas keitė krašto žemvaldžių grupès tautinę ir socialinę konsteliaciją. Kitas reikalas, kad rusų žemvaldžių sluoksnis 
aptariamuoju laikotarpiu formavosi lètai dẻl objektyvių priežasčių, nevykusios politikos, vietos administratorių skirtingo požiūrio ỉ praktinį užduoties plèsti rusų žemėvaldą ịgyvendinimą. Praktiškai šiuo laikotarpiu galima kalbėti tik apie rusų žemvaldžių grupę, kuri neturẻjo sluoksnio požymių.

Bajorų žemėvaldos apribojimas pirmąji dešimtmeti po sukilimo turèjo ir ekonominių pasekmių. Sekvestruotų ir konfiskuotų dvarų ūkis, net jeigu ilgainiui dvarai grịžo savininkams, buvo pasmerktas merdèti daug metų. Politinėmis, ekonominėmis ir socialinėmis sankcijomis buvo dirbtinai ribojama žemès apyvarta, o tai atsiliepe viso krašto ūkiui.

Gauta 20120402

Priimta 20120420

\section{Šaltiniai ir literatūra}

[1] K. Kaufmano 1866 m. birželio 18 d. raštas Kauno valstybès turto rūmų valdytojui. Kauno apskrities archyvas (toliau - KAA), f. I-62, b. 1952, 1. 14.

[2] Kauno gubernijos gubernatoriaus $1864 \mathrm{~m}$. spalio 9 d. raštas Kauno valstybès turto rūmams. $K A A$, f. I-62, ap. 1, b. 977, 1. 143.

[3] Kauno gubernijos gubernatoriaus $1865 \mathrm{~m}$. balandžio 23 d. raštas Kauno valstybès turto rūmams. KAA, f. I-62, ap. 1, b. 979, 1. 251. Komisijai vadovavo generolas majoras Aleksandras Dreniakinas, nariai: Vilniaus tardymo komisijos pirmininkas generolas majoras Nikolajus Cylovas, Vilniaus karo apygardos laikinojo auditoriato lauko vyresnysis auditorius pulkininkas Aleksandras Losevas, rūmų patarejas Nejelovas, Vilniaus generalgubernatoriaus kanceliarijos Politinio skyriaus valdininkas ypatingiems pavedimams papulkininkis Pavlovas ir Politinio skyriaus viršininkas, kolegijos asesorius Jakovlevas.

[4] Kauno gubernijos gubernatoriaus $1867 \mathrm{~m}$. birželio 20 d. raštas Kauno valstybès turto rūmų valdytojui. KAA, f. I-62, ap. 1, b. 1968, 1. 225v.

[5] Kauno gubernijos valdybos valdininko Pavlovskio 1863 m. liepos 15 d. raportas Kauno valstybès turto rūmams. Lietuvos valstybès istorijos archyvas (toliau - LVIA), f. 525, ap. 1, b. 910, 1. 23.

[6] Kauno gubernijos viršininko 1863 m. spalio 22 d. raštas Kauno valstybès turto rūmams. KAA, f. I-62, ap. 1, b. 979, 1. 88 .

[7] Kauno gubernijos viršininko $1863 \mathrm{~m}$. lapkričio 5 d. raštas Kauno valstybès turto rūmams. $K A A$, f. I-62, ap. 1, b. 979, 1. 98.

[8] Kauno liustracijos komisijos viršininko $1866 \mathrm{~m}$. sausio $18 \mathrm{~d}$. raštas Kauno valstybès turto rūmų valdytojui. KAA, f. I-62, b. 1952, 1. 6-9.

[9] Kauno miesto karo gubernatoriaus ir Kauno gubernijos civilinio gubernatoriaus Engelgardto 1863 m. liepos 10 d. raštas Kauno ir Kauno gubernijos apskričių karo viršininkams ir ispravnikams. KAA, f. I-62, ap. 1, b. 979, 1. 40. M. Muravjovo programoje valstietis buvo priešpriešinamas ne tiek bajorų luomui, kiek smulkiajai šlèktai, dažniausiai neįrodžiusiai bajorystès. Tai rodo praktiškai neigyvendintas $1863 \mathrm{~m}$. birželio $11 \mathrm{~d}$. M. Muravjovo potvarkis valstybės dvarų žemès sklypus ir sodybas, kuriose gyveno sukilime dalyvavę „šlekkta, vienkiemininkai ir kiti raznočincai“, tuoj pat atiduoti valstiečių bendruomenèms, kurios išdalytų žemę bežemiams daržininkams, trobelninkams ir kampininkams. Jeigu bendruomenès atsisakytų jiems skirti žemę, tai be jų sutikimo gali padaryti vietos valdžia.

[10] Kauno valstybès turto rūmų tarèjo 1863 m. spalio 5 d. raštas Rūmų valdytojui. LVIA, f. 525, ap. 1, b. 931, 1. 38-39.

[11] Kauno valstybès turto rūmų 1864 m. liepos mèn. raštas Kauno gubernijos viršininkui. LVIA, f. 525, ap. 1, b. 931, 1. 24.

[11.1] Ten pat. Pavyzdžių, kai sukilimo metu valstiečiai siekė patekti ị dvarų valdytojus, yra mažai. Tarkime, 1864 m. pradžioje ketinta patikèti administruoti valstiečiui Kasparui Luknaičiui kažkurị 
dvarą Panevėžio apskrityje. Paaiškèjus, kad dvaro išlaikymo išlaidos yra didesnès už dvaro metines pajamas, šio ketinimo atsisakyta.

[12] Kauno zemskinio ispravniko $1863 \mathrm{~m}$. liepos $13 \mathrm{~d}$. raportas Kauno valstybès turto rūmams. LVIA, f. 525, ap. 1, b. 910, 1. 21.

[13] S. Nikolajevo 1863 m. rugpjūčio 5 d. laiškas J. Butkovskiui. LVIA, f. 525, ap. 1, b. 910, 1. 82.

[14] Valstybès turto ministerijos $1863 \mathrm{~m}$. spalio mèn. raštas Vilniaus, Kauno, Gardino, Minsko, Vitebsko ir Mogiliavo gubernijų Valstybès turto rūmams. KAA, f. I-62, ap. 1, b. 979, 1. 68.

[15] Vilniaus gubernijos valdybos $1863 \mathrm{~m}$. liepos 4, $19 \mathrm{~d}$. ir rugsèjo $4 \mathrm{~d}$. raštai Vilniaus valstybès turto rūmams. LVIA, f. 525, ap. 1, b. 900, 1. 160, 280, 418.

[16] Vilniaus gubernijos valdybos $1863 \mathrm{~m}$. rugpjūčio $19 \mathrm{~d}$. raštas Vilniaus valstybès turto rūmams. LVIA, f. 525, ap. 1, b. 900, 1. 399.

[17] Алфавитная книга учета лиц, имения которых освобождены от секвестра, Виленская губерния. 1863 год. LVIA, f. 525, ap. 1, b. 949, 1. 1-18.

[18] Ведомость имениям, взятым уже в секвестр за участие владельцев в мятеже Ковенской палатой государственных имуществ. LVIA, f. 525, ap. 1, b. 910, 1. 276-292.

[19] Ведомость о доходах и расходах с секвестрованных имений по Ковенской губернии. KAA, f. I-62, ap. 1, b. 979, 1. 448-469.

[20] Ведомость о секвестрованных имениях по Ковенской губернии к марту 1864 года. LVIA, f. 525 , ap. 1, b. $913,1.28-46$.

[21] Ведомость секвестрованным имениям в Ковенской губернии с показанием управителей оных и чистого дохода для удовлетворения 10 процентов за управление оными. LVIA, f. 525 , ap. 1, b. 931 .

[22] Дело о наложении секвестра на имения Ковенской губернии. LVIA, f. 525, ap. 1, b. 910 , 1. $2,8,11,17,35,46,103,147,225,246$.

[23] Дело о наложении секвестра на имения участников восстания 1863 г., а также о снятии секвестра, 1863-1864 гг. LVIA, f. 525, ap. 1, b. 900, 1. 10, 106, 107, 114, 143, 152, 165, 166, 172, 192-195.

[24] Дело об отдаче конфискованных имений в арендное содержание Северо-западного края. LVIA, f. 525, ap. 1, b. 1074, 1. 14, 24, 45, 47, 58, 99 ir kt. Pvz., 1866 m. pradžioje i̇ žuvusių ar ištremtų sukilèlių dvarus pretendavo Kauno gubernijos liustracijos komisijos pirmininkas A. Goreckis, kurị domino apie 600 deš. sudarę dvarai; dèl Jokūbo Geištoro Ignacogrodo konkuravo pulkininkas Ritčeris ir Kauno valstybės turto rūmų valdininkas Šulcas.

[25] Дополнительный список русским землевладельцам Виленской губернии, 14 декабря 1871 г. LVIA, f. 378 , Bs. 1868 , b. 261, 1. 264-269.

[26] Инструкція военно-гражданскаго управленія в уъздах Виленской, Ковенской, Гродненской, Минской и Могилевской губерній. КАA, f. I-62, ap. 1, b. 979, 1. 36v-37.

[27] Инструкція Палатамъ государственныхъ имуществъ для пріема имъній подлежащих секвестру на основаніи Высочайше утвержденныхъ 15 марта 1863 г. правилъ для управленія сими имъніями и отчетности въ управленіи. LVIA, f. 525, ap. 1, b. 900, 1. 4-5.

[28] Копия отчета Виленского, Ковенского и Гродненского генерал-губернатора о состоянии Северо-Западного края за 1867-1870 годы. LVIA, f. 378, ap. 121, b. 625, 1. 52-53, 55-56.

[28.1] L. 50-51v. Susumavus instrukcinių, privalomai parduodamų ir iš varžytinių parduotų dvarų pirkejų skaičiu, jis nesutampa su ataskaitoje nurodytu bendru rusų žemvaldžių, ịsigijusių dvarų Vilniaus, Kauno, Gardino ir Minsko gubernijose, skaičiumi, nurodytu toje pačioje ataskaitoje. Matyt, rengę ataskaitą valdininkai detalizavo tik tuos duomenis, kurie rodè, kaip vykdomi pagrindiniai žemèvaldą formuojantys ịstatymai. 
[29] Копия отчета Виленского, Ковенского и Гродненского генерал-губернатора о состоянии Северо-Западного края за 1871-1873 годы. LVIA, f. 378, ap. 121, b. 651, 1. 88v.

[29.1] L. 88v-89. Pagal šią ataskaitą, Vilniaus gubernijoje lenkų kilmės žemės savininkų buvo 3 427, jie valde 1362077 deš. žemès, Kauno gubernijoje - 6195 savininkai ir 1350076 dešimtinès. „Ne lenkų kilmès“ žemès savininkų Vilniaus gubernijoje buvo 484, jiems priklausẻ 385244 deš., Kauno gubernijoje - 470 savininkų ir 340540 deš. žemès.

[30] Отчет Виленского губернского управления государственными имуществами за 1867 год. LVIA, f. 525, ap. 1, b. 1193, 1. 27v.

[31] Отчет Виленской Палаты Государственных имуществ за 1864 год. LVIA, f. 525, ap. 1, b. $1035,1.50$.

[32] Отчет Виленской Палаты Государственных имуществ за 1865 год. LVIA, f. 525, ap. 1, b. 1094, 1. 46.

[33] Отчет Виленской Палаты Государственных имуществ за 1867 год. LVIA, f. 525, ap. 1, b. 1193, 1. 28, 97-99.

[34] Отчет Виленского губернского управления государственными имуществами за 1869 год. LVIA, f. 525, ap. 1, b. 1286, 1. 11, 54-55.

[35] Отчет Виленского губернского управления государственными имуществами за 1870 год. LVIA, f. 525, ap. 1, b. b. 1323, 1. 16, 74-76.

[36] Отчет Виленского губернского управления государственными имуществами за 1871 год. LVIA, f. 525, ap. 1, b. 1367, 1. 26v, 73-74.

[37] Отчет Виленского губернского управления государственными имуществами за 1872 год. LVIA, f. 525, ap. 1, b. 1398, 1. 31v, 32.

[38] Отчет Виленского губернского управления государственными имуществами за 1874 год. LVIA, f. 525, ap. 1, b. 1450, 1. 15.

[39] Отчет Виленского губернского управления государственными имуществами за 1876 год. LVIA, f. 525, ap. 1, 1515, 1. 22v.

[40] Сведения о конфискованных в Ковенской губернии имениях. Составлено 4 февраля 1866 года. КАA, f. I-62, b. 1952, 1. 17-20.

[41] Список владельцев Виленской губернии, на имения которых наложен секвестр. LVIA, f. 525 , ap. 1, b. $900,1.583-663$.

[42] Список конфискованных в полном составе имений, в коих находится более 1000 десятин земли по Ковенской губернии. КАA, f. I-62, b. 1952, 1. 15. Kauno gubernijoje buvo tik 4 visiškai konfiskuoti stambūs dvarai: Edvardo Čapskio Kalnaberžè Kauno aps. (1 022 deš.), Stanislovo Volmerio Viduklè Raseinių aps. (3 378 deš.), Antano Jelenskio Ramuldava Ukmergès aps. (1 849 deš.) ir Jono Stanevičiaus Kaunatava Šiaulių aps. (1 252 deš.). Apie Marijono Čapskio Kèdainius Kauno aps. ir A. Jelenskio Aknystos dvarą Ukmergès aps. dar nebuvo tikslių žinių.

[43] Список конфискованным имениям по Ковенской губернии с 1 октября 1864 г. по 18 декабря 1864 г. LVIA, f. 525, ap. 1, b. 913, 1. 145-149.

[44] Список лицам, имения которых остаются под секвестром до 1 октября 1864 г. КАA, f. I-62, ap. 1, b. 977, 1. 149-168; apie savininkams grąžintus dvarus, ten pat, 1. 3-141.

[45] Список русским землевладельцам, приобретшим в последнее время имения в СевероЗападном крае и к началу 1870 г. подавшим просьбы о записке их в родословные книги по Ковенской губернии. LVIA, f. 378, Bs, 1868, b. 261, 1. 50.

[46] Список русским землевладельцам, приобретшим в последнее время имения в СевероЗападном крае и к началу 1870 г. не подавшим просьбы о записке их в родословные книги по Ковенской губернии. LVIA, f. 378, Bs, 1868, b. 261, 1. 51-54. 
[47] Список русским землевладельцам Виленской губернии, представлен 17 июля 1870 г. LVIA, f. 378, Bs, 1868, b. 261, 1. 67-98.

[48] Полное собрание законов Российской империи. Собр. 2-е. Санкт Петербург, 1866-1877. [48.1] T. 38, № 39377.

[48.2] Vilniaus gubernijoje šie skyriai buvo panaikinti 1862 m. rugsèjo 1 d., Kauno ir Gardino gubernijose panaikinti pagal $1864 \mathrm{~m}$. vasario 10 ir gegužès 4 d. ịsaką. T. 39, Ч. I, № 40581.

[48.3] T. 48, № 52255 .

[48.4] Т. 49, ч. 1, № 53116.

[49] Сборникъ правительственныхъ распоряженій по водворенію русскихъ землевладпльиев въ Спверо-западномъ крапь. Вильна, 1870.

[49.1] P. 12-18, 21-22. Pagal 1862 m. balandžio 26 d. imperatoriaus paliepimą žydams buvo leista pirkti dvarų žemę ir naudmenas, tačiau, formuojant rusų kolonizacijos Vakarų krašte politiką, buvo pripažinta, kad didžiausiais jų konkurentais įsigyjant dvarus bus žydai. Todèl $1864 \mathrm{~m}$. rugpjūčio $5 \mathrm{~d}$. Valdančiojo Senato įsakas draudè žydams pirkti dvarų ir valstiečių žemę Vilniaus ir Kijevo generalgubernatoriams pavaldžiose gubernijose.

[50] Списокъ высланнымъ из края зимлевладельцамъ Ковенской губерніи, именія коих на основаніи указа 10 декабря 1865 г. подлежать обязательной продажп( b. v., b. d.).

[51] Списокъ высланнымъ из края зъмлевладельцамъ Виленской губерніи, именія коих на основаніи указа 10 декабря 1865 г. подлежать обязательной продажп (b. v., b. d.).

[52] Списокъ импніям Спверо-Западнаго края, подлежащимъ обязательной продажп въ 2-хъ годичный срокъ, на основаніи высочайшаго повелюнія 10-го декабря 1865 года. II. По Ковенской губерніи. Вильна, 1866, с. 6-27.

[53] Списокъ импніям Спверо-Западнаго края, подлежащимъ обязательной продажп въ 2-хъ годичный срокъ, на основаніи высочайшаго повелюнія 10-го декабря 1865 года. III. По Виленской губерніи. Вильна, 1866, с. 8-25.

[54] BEAUVOIS, Daniel. Walka o ziemię. Szlachta polska na Ukrainie prawobrzeżnej pomiędzy caratem a ludem ukraińskim 1863-1914. Z języka francuskiego przełożył Krzysztof Rutkowski. Sejny, 1996.

[55] BIČKAUSKAS-GENTVILA, Leonas. Lietuvos ir Vakarų Baltarusijos žemèvaldos teisių apribojimai poreforminiu laikotarpiu (1861-1905 m.). Lietuvos TSR aukštųjų mokyklų darbai. Istorija, 1969 , X, p. 125-141.

[56] BIČKAUSKAS-GENTVILA, Leonas. Privatinès žemėvaldos apribojimai Lietuvoje ir Vakarų Baltarusijoje (1861-1905). Lietuvos TSR aukštųjų mokyklų darbai. Istorija, 1970, XI, p. 121-147.

[57] JURKOWSKI, Roman. Ziemiaństwo polskie Kresów Północno-Wschodnich. 1864-1904. Warszawa, 2001.

[58] SCHMIDT, Wacław. Geneza prywatnej rosyjskiej własności ziemskiej w b. gubernjach wileńskiej, grodzieńskiej i mińskiej (1793-1875). Z dodatkiem skorowidza majątków. Warszawa, Nakładem Głównego Urzędu Statystycznego, 1923.

[59] SMYKOWSKI, Janusz. Ukaz z 10 XII 1865 r. i jego konsekwencje dla stanu posiadania ziemiaństwa polskiego w zachodnich guberniach Imperium Rosyjskiego. Wilno i Kresy Północno-Wschodnie. Materiały II Międzynarodowej Konferencji w Białymstoku 14-17 IX 1994 w czterech tomach. T. I: Historia i ludzkie losy. Pod red. E. Feliksiak i A. Mironowicza. Białystok, 1996, s. 111-125.

[60] STALIŪNAS, Darius. Rusinimas: Lietuva ir Baltarusija po 1863 metu. Vilnius: LII 1-kla, 2009.

[51] Wykaz dóbr ziemskich skonfiskowanych przez rządy zaborcze w latach 1773-1867. Zestawił Janusz Iwaszkiewicz. Wydawnictwo Rady Naczelnej Organizacji Ziemiańskiej z okazji powszechnej 
wystawy w Poznaniu. Warszawa, 1929. Pagal šị sąrašą po $1863 \mathrm{~m}$. Vilniaus gubernijoje buvo konfiskuota 55 dvarai, Kauno gubernijoje - 9 dvarai.

[62] ГРОМАЧЕВСКИЙ, С. Г. Ограничительные законы по землевладению в Западном крае с мотивами и разбяснениями. Санкт-Петербург, 1892.

[63] ДОЛБИЛОВ, М. Д. Консервативное реформаторство М. Н. Муравьева в Литовскобелорусском крае (1863-1865 гг.). Консерватизм в России и мире: прошлое и настоящее. Выпуск 1. Воронеж, 2001. Prieiga per internetą: http://conservatism.narod.ru/sb_cons1/sb_cons1. html [žiūrèta 20120122 ].

[64] ЖИТКО, А. П. Дваранства Беларусі перыяду капіталізму. 1861-1914. Мн.: БДПУ, 2003.

[65] жУкОвИЧ, П. О русском землевладении в Северо-Западном крае со времени присоединения его к России. С. Петербург, 1895.

[66] КОМЗОЛОВА, А. А. Политика самодержавия в Северо-Западном крае в эпоху Великих реформ. Москва, 2005.

[67] ПАНЮЦІЧ, Вячаслаў. Нациянальны аспект пазямельнай палітыкі царызму на Беларусі эпохі капіталізму (1861-1917 гг.). Bełoruskie Zeszyty Historyczne, 1998, № 10, s. 41-55; 1999, № 11, s. $107-125$.

[68] Права по землтвладенію въ Западномъ крат. Б. Г. Ольшамовскаго Присяжнаго Повъреннаго. С.-Петербургъ, 1899.

[69] САМБУК, С. М. Политика царизма в Белоруссии во второй половине ХІХ века. Минск, 1980 .

[70] СТАНКЕВИЧ, А. Очерк возникновения русских поселений на Литве. Виленский временник. Книга IV: Русские поселения Ковенской губернии. Вильна, 1909, с. I-LXXII.

TAMARA BAIRAŠAUSKAITÉ

\section{Shifts of the noblemen land-ownership in the second half of the nineteenth century: sequestration and forfeiture, formation of a Russian landlord group (Kaunas and Vilnius gubernias, 1863-1873)}

Summary

The article deals with the use of a factor of land-ownership in the policy of the Russian Empire in the so-called North Western Land. Restriction of the land-ownership was a penalty to the land noblemen for their resistance to the Empire, and an instrument of the Russian nationalistic strategy. The first phase of the land ownership limitation (1863-1873) was characterized by its repressive and forcible nature. Hence, this article aims at: (1) discussing methods of the land-ownership limitation policy, such as: tenure sequestration, forfeiture, bans among which the law of December 10,1863 was exceptional as the beginning of Russian landlords' taking roots in the land; (2) reconstructing the course as well as results of application of land-ownership restrictions in the Vilnius and Kaunas gubernias.

After the uprising of 1863-1864, regulation of land property by political means did not cover economic goals. The petty, average and big noblemen landowners were the first subjects of repression in the sphere of land-ownership. Seeking to overcome 
the main rival in the fight for influence to the society of the land, the imperial authority declared "fight for land" (the term by D. Beauvois), in which it used political, social, national, and eventually economic methods. This fight continued up to the collapse of the Russian Empire.

In the first phase of this fight for land the following strategy and direction of the imperial policy was formed: to cut powers of the local elite, to create a strong social and national / confessional balance weight able to supersede the local elite from the most relevant positions within the society. In this period, due to many reasons M. Muravyov's vision to replace a social character and lean on local and brought Russian peasants was not implemented. That is why many hopes were set on transformation of the composition of the noblemen class, first of all, landowners. "New landlords", Russian and Orthodox, also Protestants, did not have to replace noblemen landowners "of Polish origin", but to counterbalance them. Also, autochthons of the land, such as Lutherans, Evangelical Reformers, and Moslem Tartars belonging to the noblemen class were opposed to the landlords "of Polish origin". A social model of the "new landlords" had to destroy the class structure of the noblemen landowners: only minor and major officials of various origins, newcomers to the land (noblemen, children of clergy, raznochintsy - a sort of officials of non-noble origin), merchants and citizens, matching criteria of national and political reliance, could become new landlords.

Results of the first phase were multiple. Applying of property sanctions to the participants of the uprising of 1863-1864 was not aimed to drive a nail into the coffin of the noblemen class, however, sequestration and forfeiture of their estates point to the existential background of the noblemen elite. Because of compulsory sale of the sequestrated estates the patrimonies were sliding from the hands of local noblemen; a degree of these losses is uncountable. Shift of patrimonial estates to the hands of "new landlords" altered the national and social structure of the landowners group. The other thing is that formation of a group of Russian landowners (it did not bear traits of a social layer) was slow because of objective reasons, unsuccessful policy, different attitudes of local administrators towards the practical implementation of the task to extend Russian land-ownership. The limitation of noblemen land-ownership after the uprising had economic consequences as well. Economy of the sequestrated and confiscated estates, even if estates came back to their possessors in time, was damned to flounder for many years. Land turnover was limited with the help of political, economic, and social sanctions that rebounded on economy of the whole land.

Key words: uprising of 1863-1864, noblemen land-ownership, sequestration, forfeiture, landowners of "non-Polish origin", Russian landlords 